\title{
How Do You Listen to Radio Moscow? Moscow's Broadcasters, 'Third World' Listeners, and the Space of the Airwaves in the Cold War
}

Radio took its star turn across the globe in the third quarter of the twentieth century. It was no new technology, of course; in many places, radio listening had become a staple of everyday life as early as the 1920s, and broadcasting figured prominently in the cultures of Depression-era capitalism, fascism, and Stalinism in the 1930s, as well as in the Second World War. But it was not until the 1960s and 1970s that radio broadcasting became a mass phenomenon worldwide, reaching not only urban populations, but rural ones, and not only in the 'First' and 'Second' worlds, but across the 'Third' as well. ${ }^{1}$ And a substantial portion of that reach - in some areas, the lion's share- must be attributed to transnational broadcasters: the BBC, the Voice of America, Radio Moscow, Radio France Internationale, Radio Monte Carlo, Radio Free Europe, Deutsche Welle, Radio Peking, the Voice of the Arabs, Radio Prague, All India Radio, Vatican Radio-a complete list would easily top one hundred, distinct transnational broadcasting operations. ${ }^{2}$ For many people around the world in the 1960s and '70s, then, radio not only entered everyday life; radio offered an entrée into a new, everyday, supra-national experience. The airwaves constituted a new transnational space for politicking and preaching, socializing and educating, for sharing and promoting cultural experience.

So far, so global. Certainly, optimism about mass media ran high among modernization school thinkers mid-century in the Anglo-American world. Broadcasting, many thought, had an exceptional capacity to push 'backward' populations into the modern world and drive socioeconomic development. ' ${ }^{3}$ Radio, film, and television climax the revolution set in motion by Gutenberg' enthused the influential American scholar Daniel Lerner in the 1950s. 
'The mass media [have] opened to the large masses of mankind the infinite vicarious universe. ${ }^{4}$ Radio development was destined to spur human development by engendering empathy, extending community, and levelling both hierarchies and borders.

If today, this pacific, communitarian vision of the twentieth-century airwaves has been overshadowed by one of combat, we can thank not only Cold War rhetoric (radio figured prominently in any discussion of East-West 'propaganda war'), but also the history of broadcasting itself. ${ }^{5}$ There was, after all, an inherent tension between the model of radio developed in the 1920s and '30s and the new realities of a global media age. As historian Michele Himes reminds us, radio, 'born in an era of nationalisms....marks a high point in the capture of a technology and a means of cultural production by the organs of the state...Radio was understood and shaped as fundamentally a national medium' ${ }^{6}$ Yet as broadcasting expanded its technical capacity dramatically after the war and decolonisation threw new audiences into the ring, radio's moment and the 'Third World' moment collided. In an era of imperial collapse and rising new nations, fundamental questions about media's role in economic and cultural development and in promoting national interests on the world stage inevitably came to the fore. Who had the right to speak to whom, and for whom? Was the transnational space of the airwaves one of mutuality or mastery? Or, put another way, whose space was the airwaves - the broadcasters' or the listeners'? In the 1970s, it was these vexed questions about media space, voice, and sovereignty that took centre stage at the UN in the New World Information and Communication Order debate that pitched First, Second, and Third World into conflict.

The Cold War so dominates our horizon for these years that we risk losing sight of cultural and social spheres that, however embedded in Cold War dynamics, did also have reference points outside them. Broadcasting is one such sphere: the airwaves in this, 
radio's moment, were a far more variegated space than today we might imagine. The leading station in the Middle East for many years, for example, was neither American nor Soviet but Egyptian-- the radical, anti-colonial Voice of the Arabs. ${ }^{7}$ Indeed, radio's moment across the globe meant the birth of many new national broadcasters outside Europe and North America, some of which broadcast transnationally, and of a huge variety of nongovernmental initiatives (e.g. Catholic-run radios in Latin America, Radio Freedom and other anti-apartheid radios in southern Africa). Across large sections of the developing world, the dominant transnational broadcasters in the 1970s and '80s were American evangelical Christians stations relaying bible-thumping sermons in multiple tongues. ${ }^{8}$ Many broadcasters, in fact, were impressively polyglot: Radio Peking spoke no fewer than thirtyeight foreign languages by the mid 1970s, ${ }^{9}$ and All India Radio, sixteen. ${ }^{10}$ The airwaves of the Cold War were diverse, dynamic, and unpredictable. Many, though not all, listeners in the Third World had options, and all broadcasters did: all broadcasters made choiceschoices about language, forms of address and style, about political and cultural content, about voice.

The Soviet Union's primary international service was Radio Moscow and, in the 1950s and '60s, it underwent a major expansion to become one the largest (and, by some metrics, the largest) broadcaster in the world. ${ }^{11}$ These years were a boom time for Soviet broadcasting across the board, but even in the context of a boom, the expansion of the international service stands out. ${ }^{12}$ Radio Moscow's growth was in both scope (more countries) and intensity (more broadcasting hours), and the decision to pursue it came from the very top; it was at once an important dimension of the post-Stalinist leadership's 'peaceful coexistence' policy, foregrounding systemic competition over confrontation, and of its related turn to the decolonizing world as socialism's putative great new frontier. The 
most prominent changes in Radio Moscow's profile were in its new outreach to Asia, Africa, Latin America, and the Middle East, the subject of multiple party decrees. Although Moscow launched multiple new language services already in the 1940s, it was in the late '50s and '60s that the volume and range of broadcasts to the Third World increased markedly. ${ }^{13}$ Reports for the period 1956-1961, for example, show a more than threefold increase in average daily broadcasts to the Arab world and document a leap forward for the Africa service from nil to seven hours daily. Further increases for Africa in 1962 and again in 1963, in response to Chinese competition, brought the total to eighteen hours and were facilitated by freeing up broadcasting stations previously committed to jamming. ${ }^{14}$

The decision to expand Radio Moscow was promoted widely at the time as proof of Soviet might, modernity, and largesse. The fact that Moscow now spoke to so many people, in so many different languages, across such vast distances, was itself a propaganda point of considerable power. The trope of Moscow's great voice breaking barriers, bringing the modern world to backward peoples, had been a war horse of domestic propaganda for decades: 'radiofication' had been an associate to 'electrification' since the 1920s. ${ }^{15}$ With the great expansion of Soviet international broadcasting in the ' $50 \mathrm{~s}$ and ' 60 s, the old horse got new legs: Radio Moscow demonstrated the Soviets' enlightened/enlightening interests in the Third World. The message could be tailored to the home audience and foreigners alike. Radio Moscow was, in this sense, very much more than the sum of its parts. The impact of Soviet broadcasting cries out for analysis not only in terms of its content, but also of its identity as an institution and of the connections with listeners it cultivated and advertised-its 'brand'.

This essay analyses the Radio Moscow brand from the inside out- that is, by looking closely how Moscow's broadcasters saw themselves, their work, and their listeners, 
particularly their Third World listeners. It is story of personal ambitions and professionalization, of ideological commitments and superpower politics. (The Cold War, though never broadcasting's sole reference point, was an unavoidable force field for all.) It is also a story of the choices Radio Moscow made about language, style, content, and voice, and the imaginative connections and even intimacy they projected. Across Asia, Africa, the Middle East, and Latin America, the actual audience for Radio Moscow, as for its international competitors, was most often a tiny proportion of the adult population, as I discuss below. Moscow's broadcasters knew this, and they also envisaged and promoted relationships with Third World listeners using a range of methods, the most important of which was a worldwide listener survey program in the years 1967 to 1982 . The twinned spaces of radio production and consumption, of broadcaster and listener, developed relationally, imaginatively, and sometimes argumentatively to create a new space: the airwaves. In what follows, I propose to explore this space as politics, as social interaction, as experience. What can the airwaves can tell us more broadly about the Second-Third World encounter as experienced in both 'worlds' and beyond?

\section{NATIONAL VOICES AND SOVIET INTERNATIONALISM}

The roots of post-war Soviet international broadcasting were in the pre-war Comintern operation, which relied heavily on political exiles (communists and fellow travellers) to produce programming. Soviet dependence on foreigners continued well beyond the Stalin era and had certain liabilities. The death of the lone Punjabi announcer in 1943, for example, meant Radio Moscow stopped its Punjabi service. Recruiting politically suitable professionals from India and other developing countries was no simple task; the Punjabi service did not resume until $1966 .{ }^{16}$ But in other respects, the model of 'surrogate' 
broadcasting had major advantages. The idea behind surrogate broadcasting (Radio Free Europe/Radio Liberty is the exemplar) was to provide a national alternative to audiences living under repressive regimes and to use the airwaves to foster a community of likeminded patriots. This was transnational broadcasting as an open-throated rebuke to state broadcasting services; it was, as the Soviets and their allies complained, inherently oppositional. But the space it offered was not foreign, by definition, but national: Hungarians speaking to Hungarians, Ukrainians to Ukrainians, and so on. In the words of George Urban (Gyorgy Ungar), RFE director in the 1980s, they were 'in effect national "home" services speaking from abroad'. ${ }^{17}$ In reality, RFE/RL not only employed many foreigners, but was a foreign operation-- funded covertly by the US government until 1971, and openly thereafter. Yet even after its funding was exposed, RFE/RL was able to make a powerful case for its own legitimacy by giving voice to nationals. Most national radio systems in the Second World ran surrogate services for their compatriots suffering under capitalism as well.

In 1957, staff from Radio Moscow's German editorial group wrote directly to Soviet Premier Khrushchev about the surrogate radio model, citing the widespread influence of RFE in what they called Hungary's 'counterrevolution' the year before. 'The formal independence of Free Europe from any kind of state power provides it with unlimited discretion, and gives it the air of being objective and impartial. Our radio is at a disadvantage in this respect [...] Moscow radio, being a state-run radio station, does not meddle in the internal affairs of other countries in conducting its propaganda. This deprives us of many opportunities to influence the formation of public opinion in those countries...' Their proposal was to develop a new, formally independent station along the lines of RFE, 
based in the USSR and in the people's democracies. 'When living with wolves, howl like a wolf', they argued. ${ }^{18}$

The German desk's proposal came at a time of not only galloping growth in the Soviet broadcasting system, but also turmoil; radio and television alike weathered an onslaught of critiques for incompetence in the 1950 s and '60s. The problems were extensive and, in many cases, intractable as the Soviet broadcasting system struggled to marry political demands to popular taste and to meet the challenges of competition in an age of intensifying media globalization. ${ }^{19}$ Radio Moscow was repeatedly criticized in party decrees for its lack of responsiveness, both to listeners' specific needs as they varied by country and to events as they developed in real time. Report from 'friends' (foreign communist party leaders) were not reassuring. The general secretary of the Syrian party forwarded a twelvepage dissection of Radio Moscow's faults with detailed suggestions for improvement directly to the Central Committee in $1962 .{ }^{20}$ American communists on a friendly visit to Gosteleradio the year before had commented that Radio Moscow's commentaries were 'a little hard on the ear' (tiazhelovaty na slukh). 'It wouldn't be a bad idea to back up your heavy artillery with humor sometimes' to appeal to the American audience, they suggested. ${ }^{21}$

In 1964, the Soviets launched a new station, Radio Peace and Progress, that in some respects patterned itself on the 'surrogate' model. With the tagline 'the voice of Soviet public opinion', the new station was an arm of the Soviet Peace Committee, the Soviet Women's Committee, the Journalists' Union, and other so-called public organizations and thus officially independent of the state. Factually, however, Radio Peace and Progress was a division of Gosteleradio using Radio Moscow equipment and supervised (like the public organizations themselves) directly by the Central Committee. With its official non- 
governmental status, Peace and Progress was seen as capable of being more dynamic and hard-hitting, and there were calls for it to be expanded. Gosteleradio head Nikolai Mesiatsev, identifying responsiveness as the Achilles' heel of Soviet media, argued forcefully for authorizing journalists to comment on news events in real time, rather than waiting for official approval - 'in the name of Soviet public organizations' - and cited Radio Peace and Progress publicly in 1966 as the model to develop further. He and others also called for a systematic program of coordination of foreign broadcasting among socialist bloc countries, the better to target resources where they would have the greatest effect and avoid duplication of effort. ${ }^{22}$ Mesiatsev's advice was not effectively implemented on either point. $^{23}$

Radio Moscow remained the jewel in the crown, and like the $\mathrm{BBC}$, the $\mathrm{VOA}$, and many other state-run transnational broadcasters in the Cold War, it was 'national radio on a large, imperializing scale' ${ }^{24}$ But as the voice of the world's first socialist state, it was also the embodiment of a new culture, socialist culture, which ensured that the people were 'not only the creators of all of cultural values, but also their masters' ${ }^{25}$ As such, Radio Moscow offered a solid ideological workaround to the question of voice, or who speaks to, and for, whom. The fact that, in the USSR, the means of cultural production were in the hands of the working class guaranteed that all Soviet media, transnational or national, spoke in the people's interest. When Radio Moscow launched its first broadcast in October 1929, the text was in German (and, later that year, French and Spanish), but its message went out 'to the workers of the world': the transnational media space it created was itself a perfect embodiment of the dream of internationalism, the borderless, global communion of labour. ${ }^{26}$ When four decades later, Radio Moscow spoke Swahili, Vietnamese, Arabic, and sixty-plus other languages, the circle widened in practical terms, but the people's interest 
remained indivisible, the identification of Soviet national and socialist international, complete. $^{27}$ Or, to quote a 1964 Soviet textbook on international relations: 'The only true internationalist is he who supports the USSR. ${ }^{28}$

The question of voice, however, remained vexed all the same. On the one hand, Radio Moscow's very identity was defined by its mission to project and promote the USSR. On the other, Moscow, as champion of Third World national liberation struggles, prided itself on giving voice to the voiceless, the silenced and oppressed. Tension between these two poles was inescapable. 'Only socialism makes the press serve all the people', Khrushchev lectured Third World journalists gathered in Moscow in 1963; it was necessary to seize the means of cultural production. ${ }^{29}$ But who best, then, to speak for socialism in the new nations of the Third World? Whose space was the airwaves?

\section{SPEAKING TO AND SPEAKING FOR}

Like all Soviet institutions, Radio Moscow structured its relations with the non-Soviet world in geopolitical, hierarchical terms. The largest editorial groups at Radio Moscow, and the ones with the largest budgets, were always those broadcasting to the Soviet Union's Cold War rivals and to friendly socialist countries in east-central Europe. We might chalk this up to the predominance of English worldwide and to far greater numbers of speakers of European languages in the USSR than, say, Gujarati. But the dominating position of the West was always more than purely pragmatic in nature. The US had, as the Soviets periodically complained (and blamed on American government manipulation), a tiny short-wave radio listening audience, and yet investments in the American operation ran high; the staff on the editorial group working for North America dwarfed that for any other country. 
In more subtle ways, too, Radio Moscow's institutional life revealed its vision of the world. When administrators wrote up reports on their global operations, they not only divided the world into zones- 'socialist', 'capitalist', and 'developing'- but also presented their findings unfailingly in that order. This was also the routine order for all meeting agendas. Memoirs and other first-person sources make it plain that the most prestigious postings for the press and the diplomatic corps were in the West. ${ }^{30}$ Natasha Beglova, daughter of an elite international journalist, recalled a family acquaintance's shock that her father had not interceded to have her diplomat husband posted somewhere other than Bangladesh. Her father, a socialist true believer, told her it was her duty, but pitied her all the same. ${ }^{31}$ The geopolitical ranking was clear, and people knew where they stood. ${ }^{32}$

In this sense, to say that the developing world was ever the apple of Radio Moscow's eye is a distortion. The bipolarity of the Cold War may wear thin analytically today, but it was very much a reality of everyday life for the people who made Cold War cultures. Still, Radio Moscow, did expand the scale of its broadcasting to the Third World substantially beginning in the 1950 s and, what is more, it did so in very specific ways. In sheer volume, Soviet broadcasting to Asia, Latin America, Africa, and the Middle East never matched that of its broadcasting to the West; nor, for the most part, did it match the level of its Cold War rivals. In Radio Moscow's Third World operations, more striking and more telling in many ways than either the size of the staff or the number of broadcasting hours was the number of languages it spoke.

Moscow, more than any other transnational broadcaster, committed itself to speaking in the listener's native tongue. The policy was far more than practical; in fact, in some cases, where linguistic expertise was short on the ground, and when many potential listeners were functional in a major western language like French, it was highly impractical-expensive, 
cumbersome, and inefficient. In the Khrushchev era, the files of the broadcasting administration, like those of many other institutions, are peppered with directives and plans to train more language specialists. Only $5 \%$ of Radio Moscow employees were members of foreign communist parties in $1961 .{ }^{33}$ One Norwegian representative of that group, Morten Jentoft, sent by the Norwegian communist party in the 1950s, noted a marked change from the late '50s on, as new language specialists came to outnumber the old timers. He also detected a demotion of Norwegian in Radio Moscow's attention and a growing emphasis on the new nations and languages of the Third World. ${ }^{34}$

How should we understand the huge premium placed on native tongues, if not native voices? Many of young people who came to work at Radio Moscow (and other foreignfacing institutions) trained in an area studies framework, and not all of them graduated with strong language skills. One journalist, who later went on to work at Radio Moscow, recalled in a 2016 interview how mightily he had struggled to understand his hosts on his first post abroad - in his case, as a translator in Cuba; he, like many in his cohort, had little exposure to the living language and saw himself as a regional or national specialist first. ${ }^{35}$ We might imagine that with experts like this, Radio Moscow was finely tuned and highly differentiated in its approach - one message or genre for west Africa and something very different for, say, Egypt or Finland or Mexico. This was the image conveyed in the Cold War press in the US, which fretted paternalistically at times about populations in the Third World lacking the sophistication to resist communist broadcasting masterminds. ${ }^{36}$ It was also the image Radio Moscow promoted about itself, both internally to radio staffers and externally to domestic and international publics. But the reality of day-to-day broadcasting was rather more routine. 
Radio Moscow did sometimes adapt its approach to target audiences, as scholars have demonstrated in relation to specific events, such as the Suez Crisis and the Chilean coup, as well as to more open-ended campaigns, including the targeted use of Alfred Schnittke's composition Nagasaki in anti-nuclear, anti-American programming to Japan in the 1960s and of child-focussed anti-war programming for Vietnam in the $1970 \mathrm{~s}^{37}$ We also have some evidence of editorial groups pursuing in Moscow could be responsive to signals from Soviet embassies. ${ }^{38}$ Personalities could come into play. The long-term employment of specific announcers, who sometimes enjoyed, relative to domestic Soviet broadcasting, greater latitude to develop their own on-air personas, had an impact on the tone of different editorial groups' broadcasts. (Joe Adamov, who featured on the North American service for thirty years, is a prime example.) $)^{39}$ Yet while Radio Moscow did allow some scope for variation, it was also well known among media professionals as 'the tomb of the unknown journalist'. The sobriquet had a twofold meaning. Not only were RM staff unknown to listeners within the USSR and little known outside it (given the tiny audience size), but much of what the work they did was not, to their journalists' eyes, journalistic . ${ }^{40}$

The great bulk of Radio Moscow programming was produced and standardized centrally ('simply "came down" from the top' said Norwegian Jentoft): central editorial groups wrote texts in Russian in set categories, and editorial groups for the different regions translated and recorded them for broadcast. Renata Lesnik who worked on the Hungarian desk in the 1970s, recalled she and her colleagues referred to the boxes where they collected these texts as 'the feeding trough'. ${ }^{41}$ According to Radio Moscow's in-house journal, 'Foreign Broadcasting Bulletin', the role of materials from these central sources actually increased as of the mid-1960s in response to 'increased anti-Soviet imperialist propaganda'. ${ }^{42}$ For a sense of the themes, we can look to the collection of texts for use in foreign broadcasts 
published in the 'Bulletin' in 1971: 'The leading role of the communist party', 'The Communist Party of the Soviet Union (CPSU)- organizer of five-year plan fulfilment', 'Why does the USSR have one political party?', 'Who can become a member of the CPSU?'43 Reports from foreign correspondents were rare, as were interviews and unscripted, 'talk show' format broadcasts, such as Adamov's long-running show, 'Moscow Mailbag' ${ }^{44}$ Looking at the schedules for any given day across the world, a large share is identical. I will return to this theme below, but for now, I want to query again the commitment to native languages. Given the limited resources, why bother?

The fact that the territory of the Soviet Union was itself famously polyglot and had a complex history of language politics is important here. Soviet nationality policy tended to fuse linguistic and political identity. In the USSR, while not every language group had a state formation (in the Soviet sense-- socialist republic, autonomous republic, etc.)-indeed, most language groups did not-- every state formation had to have its own language; most people in Belorussia may well have spoken Russian day-to-day, but an essential part of what made their state theirs, the BSSR, was that they had a language, Belorussian. Language in this sense trumped ethnicity because language was understood to be the bedrock of national culture. Soviet modernization ideology regarded cultural development grounded in native language as a critical component of overall economic and political development. ${ }^{45}$

In the everyday of the USSR, all sorts of institutions and attitudes worked to promote Russian-language dominance. Khrushchev, and later Brezhnev, spoke enthusiastically about Russian as a lingua franca and, more radically, about the coming 'merger' of nations that would liquidate cultural barriers once and for all. But the equation 'language-culture-state' remained valid and potent. Language was always about much more than communication; it was about culture, and culture was about mastery (the people as culture's masters) and 
respect. The identification was mapped out very clearly in international relations textbooks, which cautioned budding diplomats that the language chosen for negotiations held 'great political significance'. The fact that Bengali had been designated the working language in Bangladesh's negotiations with the USSR, a first 'for a young state, fighting for its to international recognition...attracted huge attention throughout the world and especially inside the country itself', one text explained. ${ }^{46}$

It is to this kind of language politics that we must look to understand the structures and mores of Radio Moscow. Broadcasting was coded as enlightenment (the electrification of the mind), and enlightenment, or cultural development, was best realized in native tongues. Broadcasting was also, in the transnational context, a kind of disembodied mobile embassy - radio as diplomatic mission--where respect for the culture of the host country was crucial. Respect was best concretized in language. It is a point Frederick Barghoorn, a canny contemporary scholar (and former press attaché in the US embassy in Moscow) made as far back as the 1950s. 'Soviets leaders...,' he wrote, 'have demonstrated considerable sensitivity to the self-image of almost every kind of national and cultural group. They seem to realize more clearly than Americans or even Western Europeans that one of the most effective ways of flattering an individual is to express appreciation of his national language, literature, and art' $^{\prime}{ }^{47}$ Finally, size, or scale, mattered- a point noted by historians of Soviet science and technology, but no less valid, in its own way, in communications and culture. Polyglot Radio Moscow embodied Soviet 'gigantomania', or fascination with large-scale, standardized projects. ${ }^{48}$ The sheer number of broadcasting languages was indexed to the Soviet Union's might, modernity, and leadership on the world stage.

What this meant in practice was that the space of Radio Moscow production was an extraordinary combination of diversity and sameness, cosmopolitanism and mono- 
culturalism. Radio Moscow pursued its audience primarily through language; its linguistic diversity went unmatched and cannot be dismissed. This was the giving of voice, of a kind the airwaves as a space of linguistic and cultural assertion for populations around the world. Yet Radio Moscow also created a space of great sameness and uniformity, a worldwide mono-culture of socialist internationalism. It would be a mistake, however, to conclude that this mono-culture was generated automatically, or carelessly, with no thought for the audience. On the contrary, its standardized form was very much calibrated to an abstract, imagined audience.

Exhortations to know the audience and tailor production to the audience were a constant feature in the broadcasting world; they appear routinely in criticism and selfcriticism, in audits, in decrees improve the service, from the 1950 s on. ${ }^{49}$ Broadcasters worked according to plans: take the 'Plan to propagandize the decisions of the CPSU September 1965 Plenum' for example. Each of the editorial groups produced a list of programs they planned to produce in conjunction with the plenum - titles and short descriptions - which they then presented to the central radio administration, which presented them to the relevant CPSU department for approval. The plan specified that broadcasts would be 'differentiated' into three groups: socialist world, capitalist world, developing world, with the following emphases: broadcasts to socialist countries were to stress the Soviet Union's role in building the material-technical base for communism in the interests of the whole socialist camp; developing countries would hear most of all about the superiority of socialism over capitalism for economic development, and about how the economic development of USSR was in their interests; and broadcasts to the capitalist world would unmask the lie that the Soviet system was moving toward convergence with capitalism. ${ }^{50}$ The radio administration discussed these plans at the highest level: Mesiatsev, 
generally approved them, though he worried that they were overly defensive where they should be offensive ('we need to attack and attack, beat, hit') and too far removed from the necessary 'historical' approach. What they needed to do, he said, was 'demonstrate more widely and more fully to every country, using historical examples from our country, the experience of our country, the experience of building socialism over every year of the existence of the Soviet state. ${ }^{51}$ Differentiation was a matter of emphasis or shading, and though it is not uninteresting (more on this below), the fundamental message was the same. ${ }^{52}$ It was targeted to the audience, but not about the audience; it was about 'the experience of our country'; it was about the USSR.

Of course, we might answer. What else would it have been about?, we might ask. (The BBC External Service's mandate was, for a time, 'the projection of Britain'. The Voice of America was the voice of America.) But we might also remind ourselves of the visionary connection in Soviet history between radio and enlightenment, and between radio and empowerment (giving voice to the voiceless), and, indeed, of the rediscovery of the Third World in the 1950s and all those trained-up area specialists sitting at their desks. We can reclaim our ability to imagine options. The surrogate radio model was one; mass education and mass entertainment were others. Radio Moscow broadcasting to Africa did have the choice to broadcast about Africa, to Latin America about Latin America, or to both about each other, and so on.

Instead, the pattern of coverage of Third World news broadcast on Radio Moscow showed a strong kinship with that of the VOA and other western broadcasters: when an African, Asia, or Latin American country was discussed, it was in the context of the relationship to the broadcasting nation (what the US, USSR etc. is doing in X country), of problems and negative events (crises, natural catastrophes etc.), or of East-West conflict. 
Algeria was unlikely to hear about Indonesia and vice versa (barring crises) and Algeria and Indonesia heard very little about themselves unrelated to the Soviet world. The Cold War context and the identity and activity of the broadcasting nation, in other words, thematically overrode all other considerations. The Third World nation itself was instrumentalised. The space of the airwaves was not its own. ${ }^{53}$

In the 1970s, it was precisely these issues that gave rise to accusations of western media imperialism from the Third World nations and calls for a New World Information and Communication Order (NWICO) under the auspices of Unesco. Here, the Soviet Union joined a coalition of African, Asian, and Latin American states (many part of the Non-Aligned Movement) to demand a more equitable distribution of media resources worldwide, meaning not only technical resources, such as radio frequencies and satellite access, but also the resources of voice and space. The argument was that the domination of global media by Western corporate and state interests inevitably led to the exclusion and distortion of Third World stories. African, Asian, and Latin American nations had the right to occupy transnational media space on their own terms- to tell their own stories, in their own voices. ${ }^{54}$ Among the proposed solutions were a UN-funded Third World news pool, to counter the hegemony of Western news agencies, and increased international regulation of media operations to ensure each nation's 'informational sovereignty'.

On the level of state policy, the USSR and its allies in Eastern Europe were vigorous proponents of the NWICO. The Soviet Union's own transnational broadcasting never embodied its model, nonetheless, and it what did embody was no less universalizing (and, arguably imperialistic) than its western competitor: the polyglot, mono-culture of socialist internationalism. The point was not lost on many policymakers in the Third World who, though making common cause with the Soviet bloc in the NWICO struggle, sought to limit 
bloc culture in their own countries as much as, and sometimes more than, Anglo-American. Support for stiffer regulation of transnational media flows, in other words, suited different parties for very different reasons. Ironically, Soviet-sponsored initiatives (for example, to restrict direct satellite broadcasting) were embraced by many Third World leaders as protection against Soviet broadcasting..$^{55}$

\section{RADIO MOSCOW KNOWS ITS AUDIENCE: THE WORLDWIDE SURVEYS}

For an enterprise that involved so many thousands of hours of labour, that so preoccupied political authorities and publics, it is remarkable how little is left of Soviet transnational radio broadcasting and, in particular, broadcasting to the developing world. True enough, the archives in Moscow are crammed with the authorized scripts, and thanks to Cold War-era American and British monitoring services, we have an enormous stock of transcribed broadcasts worldwide as well. ${ }^{56}$ Determining what was said to whom and when, while not always easy, is not the problem. How did Radio Moscow talk to its Vietnamese audiences about American racism?: what did Radio Moscow say around the globe on the $100^{\text {th }}$ anniversary of Lenin's birth?; how did Radio Moscow frame the politics of the invasion of Afghanistan in 1979?- all of these are knowable things, and there is analytical mileage to be gained in knowing them. ${ }^{57}$ But radio is more than texts: radio is producing and consuming - both activities embedded in social contexts and also themselves social (or parasocial) interactions. At least as important as knowing what was said is how it was said, and how it was heard. ${ }^{58}$ Scholars have postulated that the nature of short-wave broadcasting technology conditions the kind of space it creates for listeners: because listening very often involves searching for frequencies and coping with interference, the shortwave listener must be more committed and, by extension, emotionally invested. ${ }^{59}$ There are traces of a 
bygone listener culture for Soviet bloc radio stations on the web today (QSL cards and other memorabilia, for example, posted by former hobbyists), but little more. An important forum for Cold War-era sociability once embodied in sound now sits on the page, stony silent.

Simo Mikkonen, a pioneer in the history of Soviet foreign broadcasting, concludes this realm of sociability must remain elusive: 'any far-reaching conclusions about the audience are impossible to make'. ${ }^{60} \mathrm{He}$ is in good company, given the notorious difficulty of reception studies. Even media ethnographers-- people who watch other people watch TV, for example-- struggle to come to analytical terms with their observations and what they tell us about audience engagement. They are troubled by the problem of extrapolation from the specific to the general and aware that the questions they ask have everything to do with the audience they 'get'; or to put it another way, the audience they can imagine is the audience they find, and not necessarily the audience in a global sense. ${ }^{61}$ This problem of imagination touches people broadcasting at least as much as social scientists studying it. Radio Moscow was no exception. Its five worldwide audience surveys, conducted between 1967 and 1982, show broadcasters finding an audience, responding to an audience, and attempting to build relationships with an audience. The data they collected are, as we shall see, overwhelmingly and fascinatingly subjective, with a great deal to say of about how Radio Moscow saw itself and the world. Yet for all their subjectivity, they can also help us reconstruct something of a portrait of listenership for Radio Moscow and further our understanding of the airwaves as an interactive social and political space.

Throughout the Cold War, western broadcasters sometimes went to extraordinary lengths to research their audiences in the Soviet bloc: dummy post box addresses were 
established so would-be correspondents might write in undetected by the local authorities; researchers were sent incognito to trade fairs and other international venues to chat up guests from the Soviet bloc about their listening habits. ${ }^{62}$ Research on audiences in other parts of the world was both more straightforward and systematic. The BBC, VOA, and other western broadcasters regularly commissioned market and opinion research firms to conduct listener studies across the globe. A 1988 article by the former Head of International Broadcasting and Audience Research at the BBC, Graham Mytton, summarizing these findings gives a sense for the overall dimensions for the Third World. In Nigeria in 1983, for example, BBC compiled data showed regular audiences (as a percentage of the adult population) ranging from 12.9 for the $\mathrm{BBC}$ to 1.9 for Eternal Love Winning Africa, an American-funded evangelical Christian service, with Radio Moscow at 2.4. In Peru that year, the highest share was for another Christian station, HGJB the Voice of the Andes (7 percent), with the $\mathrm{BBC}$ coming in at 4.2 and Radio Moscow at 1.8 , roughly the same as Deutsche Welle. Audiences shares did bulge in some regions: in Asia for the BBC and All India Radio, for instance (one-third of Bangladeshi adults for the BBC Bengali service, 1983), or in Dakar, Senegal for Radio France International in French (nearly forty percent in 1987). But across the board, region by region, the tables are dotted with single digit and fractional percentages for all transnational broadcasters. Radio Moscow did not pass the single-digit barrier in any region. ${ }^{63}$

In the Soviet Union, sociological research of the type used to produce the BBC's statistics had a chequered history. For a brief period in the 1960s, the broadcasting administration did have a 'scientific-methodological' department, a media sociology division, which conducted formal research on the domestic Soviet audience using surveys and statistical modelling. But the department was very short-lived; in the more conservative political 
context of the 1970s (post-1968), media sociology was deemed unnecessary, and possibly disruptive, for domestic broadcasting operations. The time-honoured tradition in Soviet media was to rely on written correspondence to assess the audience-in effect, to equate mailbag and audience. ${ }^{64}$ 'No matter what its contents and who wrote it, the very fact that it was sent to us can be considered as proof of the effectiveness of our broadcasts,' declared Radio Moscow's in-house journal. ${ }^{65}$ Like all Soviet media operations, international radio received a huge amount of mail (upwards of 100,000 letters a year in the 1960s and over 200,000 in 1975) ${ }^{66}$ and devoted considerable resources to it; letters were translated into Russian, read, and categorized by theme, discussed and used in program planning; every letter earned a reply, at least in theory (practice evidently sometimes lagged), and many letters also triggered souvenir gifts. Editorial groups organized contests to stimulate correspondence, such as 'What do you know about the USSR'?, a quiz put on by the Latin American desk in 1956 and answered by 140 listeners, each of whom got a small prize, such as a set of postcards or a book. ${ }^{67}$ In 1973 alone, Radio Moscow sent out 290,000 letters and packages. ${ }^{68}$ Editorial groups were judged by the volume of their correspondence and, to a lesser extent, by how prompt was their response.

The Radio Moscow worldwide survey program represented a singular mode of research: a hybrid of the Soviets' great letter fixation and the sociological survey model. In scope and complexity, it was a remarkable operation. The first of the five worldwide surveys, in 19661967, entailed distributing 73,000 questionnaire forms (one-two pages) printed in no fewer than thirty-nine languages. Subsequent studies, in 1970, 1974, 1980, and 1982 were larger still: 89,000 questionnaires in forty languages for 1974 study, an astonishing 137,000 in forty-six languages in 1980. Completed surveys were returned to Moscow to be tabulated, translated into Russian (the open-ended questions, typically two of fifteen), and analysed. 
As in any survey research, distribution numbers dwarfed returns, but even at the overall rate for the 1974 survey, $23 \%$, this still meant over 20,000 items to be processed. As of 1974 the records mention using a proto-computer (punch card) system located at the USSR Council of Ministers. But even this brave new world of automation still meant sifting through mountains of correspondence by hand.

Thinking about Radio Moscow's research program, we need to visualize those mountains of hand-written letters and survey forms, and imagine the individuals with the linguistic abilities to process them - the rare Gujarati speakers of Moscow, the Swahili, the Arabic, the Japanese. How often would these people have had contact with native speakers or seen the native language penned? Piece by piece, they translated faraway voices into Russian, coded them for use on the proto-computer system, then counted them, sorted them, and studied them. The reports they produced bristled with impressive-looking statistics, with percentages calculated to the decimal point. (I have rounded them up here.) But the research process itself was intimate and laborious, and in fact, the hard work of knowing the audience had begun long before and fed into the research design. ${ }^{69}$

Radio Moscow's distinctive research method was to survey only its known and presumed listeners; it eschewed sampling and other techniques. The title of the first survey, 'How Do You Listen to Radio Moscow?', is indicative of its approach. Known listeners were people who had corresponded with them in the past and were logged, by hand, in its extensive card catalogue system; in theory, every single person who had ever written in- to ask a question, make a suggestion, participate in a quiz-was meant to receive a Radio Moscow survey form. Presumed listeners were defined as members of friendship societies and other communist-party affiliated groups, local Friends of Radio Moscow clubs, and Russian-language students. 
The approach was a pragmatic one, no doubt- a palliative for genuine headaches with survey distribution, particularly in the developing world. But much more than that, I think, it was also a principled stance, motivated by ideas of self and other. When Radio Moscow staff discussed research results in their in-house journal, for example, they consistently (and at least in print, unreflexively) substituted the set of the letter writers and survey respondents for the audience as a whole. The individuals in their address books were not seen as a self-selected group; they were their listeners. And the task at hand was not so much to respond to their opinions, but rather to know their opinions in order to assess to what extent they were 'prepared for the reception of our programs'. ${ }^{70}$ In other words, although Radio Moscow was working through broadcasting's innate blindness no less than the $\mathrm{BBC}$ or any other international broadcaster, its research method obviated the problem and made the imagined listener real, tangible, and visible. My point is not that Moscow's broadcasters were wrong about their audience. (We do not know.) My point is that they did not see themselves in their research; they did not conceptualize the problem of their own imaginations.

Who was it that Radio Moscow saw via its research? Unsurprisingly, listeners appeared divided- first, by historical stage of development (socialist, capitalist, developing) and second, by language. Whereas production was organised geographically (the Latin America editorial group, the Japan editorial group), survey results were always grouped in developmental terms for analysis: Colombian alongside Cameroonian, but not Cuban, Vietnamese with Polish and Hungarian, but not Indonesian. Within this framework, the socialist and capitalist worlds had the bigger presence. Listeners from the socialist bloc and the capitalist world dominated both the Radio Moscow mailbag and the survey returns: not only did a larger number of surveys get distributed in those areas, but they also had a higher 
rate of return. To give one example, of the 30,000 surveys returned for the 1980 study (from a total of 137,000), 14,000 came from the socialist world, 10,000 from the capitalist world, and 4000 from the developing world [sic]. ${ }^{71}$

As viewed through the prism of the surveys and other correspondence, the three worlds' audiences were thought to differ in some basic respects. As a rule, capitalist world listeners were most likely to criticize programming and to express political opinions at odds with the Soviet line; developing world listeners were most likely to write about Soviet foreign policy and to express praise and gratitude for Soviet aid and for Radio Moscow itself. ${ }^{72}$ Socialist bloc listeners distinguished themselves by addressing Radio Moscow as an institution with some familiarity. A good number wrote about themselves and asked for help of some kind - sorting out housing problems, for instance-and offered suggestions for improvement in programming based on their domestic radio services. ${ }^{73}$ But both socialist and developing world listeners often expressed themselves using stylized political language- the language of the propaganda pamphlet or, for that matter, the Radio Moscow broadcast. 'The decisive role in the crushing defeat of imperialist Germany belongs to the world's first socialist state. This victory marked a fundamental historical breakthrough: the founding of the socialist camp and collapse of the colonial system', wrote a listener from Argentina in $1975 .{ }^{74}$ 'Today all Somalis understand that they are the builders of their own country's future', read a letter from Somalia that same year. 'It is the Somali Revolution that gave them this power, bringing to their lands the ideas of Great October, of MarxismLeninism' ${ }^{75}$ A listener in Syria wrote to say: 'a celebrated event in the life of the Soviet people will take place in the coming year: the $25^{\text {th }}$ Party Congress of the Communist Party of the Soviet Union'. He continued, 'The peoples of the Arab countries delight in the 
achievements of the Soviet Union whose flag has been flying over the planet for fifty-eight years already, inspiring people in the struggle for justice'.$^{76}$

Although Radio Moscow considered developing world listeners its most complimentary on the whole, its reports are also full of their suggestions for improvement, usually in response to an open-ended question on the survey. ${ }^{77}$ These ranged from general recommendations for things like changes to broadcasting schedules and programming ('More programs for the former Portuguese colonies. Your programs really help us build socialism', wrote a man from Guinee-Bissau' ${ }^{78}$ and 'unmask the reactionary essence of imperialism, Zionism, and Maoism more actively', suggested a Tanzanian $)^{79}$ to the very specific. 'You should devote time every day, if only five to ten minutes, to the high principles of V.I. Lenin...' (India); ${ }^{80 ~ ' B r o a d c a s t ~ m o r e ~ i n t e r v i e w s ~ w i t h ~ f o r e i g n ~ g u e s t s ~ i n ~ t h e ~}$ USSR [...] In part, I would like to hear Africans themselves comment on African events' (Nigeria);', 81 or 'Introduce a program 'Letter of the day' in which you would name the author of the most interesting letter' (Pakistan)..$^{82}$

Listeners often complained about announcers' archaic language and pronunciation; one sent a detailed list of specific sounds (in Bengali in this case) for them to work on; while another offered: 'Try to be closer to conversational language. Take the BBC and VOA as an example' ${ }^{83}$ Music was another frequent focus, in particular, requests to broadcast less Soviet music, and more music from the listeners' regions. A young man from Israel wrote to say he did not think Radio Moscow paid enough attention to 'Arab and Eastern songs. But you are broadcasting for Arabs after all. Your broadcasts should give Arabs the chance to feel that only they are being broadcast to' ${ }^{84}$ 'Soviet music is probably very good', offered one listener, 'but it's not popular in East Africa, so broadcast African music. ${ }^{.85}$ 


\section{TOWARDS AN (NOT THE) AUDIENCE}

Radio Moscow's audience materials present a seductive combination of precise maths ('47.6\%') and first-person expression. But they are not scientific studies, and interpreting them presents challenges on multiple levels. To begin, we should be clear that what we have are not the surveys and letters themselves, which were not archived, but rather excerpts chosen by Radio Moscow staff: selected quotes from a self-selected groupa subset of a subset. (I will return to this point later.) We know that citizens of socialist countries, at least, did approach their domestic media in similar ways: to ask for advice and assistance and to signal political allegiances. (Radio Moscow commented drily: 'evidently, the Polish desk at Radio Moscow is now considered a division of Radio Poland', as Polish listeners wrote requesting, among other things, sheet music and television parts, advice about how to choose a university, and medical interventions. $)^{86}$ But what are we to make of listeners from Asia, Africa, Latin America, and the Middle East writing to Moscow to praise Brezhnev, laud the heroism of the Soviet people in the fight against fascism, and ask for more of what was, after all, the very bread-and-butter of the broadcasting schedule (Lenin, Soviet foreign policy, the history of the Soviet stroi and so on)?

One point to consider is the process that went into preparing the audience materials we have; it goes without saying that the selection of quotes from surveys and letters was tendentious, and we cannot be sure what did not make the cut. Renata Lesnik, whose very first task as a new hire on the Hungarian desk was to prepare a program 'We Respond to Our Listeners', recalled that when she wanted to answer a lengthy letter accusing the USSR of inflaming tensions in the Third World, a colleague told her it was clearly from one of their 'crazy' correspondents (they kept a list) and she must ignore it. 'We don't argue with crazy people'. She was counselled told to look for letters from 'our faithful friends, like Malych, 
from the Koposzvar [sic] Meat Factory' who wrote 'wrote about interesting topics and exactly as needed'.87

In some cases, the comments from Third World respondents are so polished as to read like one of Radio Moscow's own broadcasts; in others, they read like a rehearsal for something, as if the person writing were practising a language, flexing its muscles. Some correspondents did mention that they relied on Radio Moscow for their work in political agitation, and given the connections between radio listening and educational institutions (Russian-language clubs, political study groups), a performative element makes some sense. ${ }^{88}$ Lesnik noted, too, that many of the letters she saw had been written by students as a class assignment. It is also worth thinking about how actively Moscow encouraged people to write, distributing souvenirs and making it clear that everyone stood a chance of having their letters read on air; they also ran regular lotteries with prizes to stimulate survey returns. Some listener input shows a keen awareness of these incentives. 'I think it is essential for you to improve your work with listener letters: your answers often arrive with great delay. I advise you to send listeners photos of RM staff and souvenirs, as do the BBC and Deutsche Welle, for example', wrote a Nigerian student. ${ }^{89}$ Other correspondents bring in elements of playfulness and friendly flattery. 'I get a great deal of pleasure from your broadcasts', wrote one Indian peasant listener. 'We get a lot of interesting and useful information about the Soviet Union and the world situation from them. You write that you will send listeners a present for participating in this survey. I think that we are the ones who should send you presents for your work' ${ }^{90}$ There are notes of formality and informality, of artificiality and of what comes across on the page at times as heady political exuberance. Interpreting this global chorus of voices effectively would mean somehow getting to grips with what the basic act of writing and listening to Moscow-and listening to radio $\underline{\text { full }}$ 
stop-- meant in vastly different contexts. Anthropologist Debra Spitulnik dissects this point powerfully in her work on radio in Zambia. 'From both an ethnographic and theoretical standpoint', she writes, 'we need to remain aware that the individual interpretive moment of decoding a media message may not be the only-- or, indeed, the most significant-aspect of what a particular media form "means" in a given sociocultural context....the impact of a media technology changes with both its context and the activities [e.g. cooking, cleaning, driving, socializing] that accompany it. This forcefully suggests how media create social spaces but simultaneously merge with them' ${ }^{91}$

Radio Moscow's two largest cohorts of correspondents in the 1973 were the Polish and the Japanese, and yet it is hard to imagine two settings more different than 1970 s Poland and 1970s Japan. Roughly the same number of letters came to Radio Moscow that year from Bangladesh (687) as from Tanzania (693) but was there anything else to link them ${ }^{92}$ What did it mean to complete a survey in a Quechua-speaking village in Peru sent by the only broadcaster in the world who spoke your language, in Moscow, when compared to the experience of corresponding from, say, New Delhi or Algiers, where the airwaves teemed? Is there anything to connect these varied experiences?

How Radio Moscow broadcasts merged with social spaces across the world depended on a wide range of factors, as identified by media scholars in other contexts: the nature of the technology used (portable or fixed radio sets); ownership practices and the status of radio listening in a given social context (who controlled the set?); the quality of the signal, and whether listening demanded close attention or allowed people to continue other activities, such as housework, at the same time (a key factor in the gendered use of media worldwide, researchers have found); the legality or illegality of listening; to name but a few. Spitulnik herself found that in Zambia at that time of her research, the late 1980s, the radio 
experience was shaped predominantly by the mobility of the technology in use (transistor) and the ways that radio listening interacted with local kinship patterns and status relations. The ownership of the radio space was not only a metaphorical question, but a literal one with real-life consequences for how people were and were not able to listen and interact with the information broadcast. ${ }^{93}$

There are some hints in the surveys and letters about listening practices around the world. The issue was one that interested Radio Moscow, which held strong opinions about what constituted good listening. The ideal, or 'active listener', was one who listened in a group, rather than alone, who listened regularly (preferably daily and over a long period of time, not sporadically), who listened to specific programs, as opposed to tuning in haphazardly, and finally, one who was in contact with Moscow. ${ }^{94}$ Surveys were in fact partly a 'listener activation' technique (Radio Moscow's term), a method for getting people involved; several of the questions addressed these points directly (e.g. 'How often do you listen to RM? Daily/2-3x per week/a few times per month/once per month or less'), and so Radio Moscow had some data at its disposal to say that listeners in certain regions were more likely to tune in as groups than as individuals, or that people in one of the three 'worlds' tuned in less frequently than another. Considering these hints, we need to keep in mind the specificity of the survey, its self-selectivity, along with the very selective nature of the data Radio Moscow generated about it. It makes no sense based on this data to speak of the 'Third World audience' for Radio Moscow, or the African one, or even, say, the Ethiopian.

Yet even so, Radio Moscow research does tell us about something about someone, about an audience, if not the audience: the people Lesnik's colleague tagged as 'faithful friends', the substantial group of people who took the time and expense to write. And from 
this group, a portrait emerges marked overwhelmingly by two characteristics: youth and male gender. The predominance of young (under thirty) men in the group is mostly consistent worldwide, but particularly striking for the Third World, where in some countries it reached well over $80 \%$ of listener-correspondents, a large proportion of them students. ${ }^{95}$ The space of Radio Moscow and institutional educational spaces very clearly overlapped, particularly with reference to Russian language teaching. ${ }^{96}$ References to studying Russian in the letters and surveys are very common. What is more, the general portrait of the listener as young man can be shaded in with some details (again, based on the research): he was someone interested in politics, above all, eager to learn, pro-Soviet, urban, and inclined to listen often with friends and family. ${ }^{97}$ A significant proportion of listeners in Radio Moscow's files were also repeat correspondents: they listened to Moscow, wrote letters to Moscow; they cultivated a relationship. Radio Moscow understood them as the future leaders of their countries, but also elided the distinction between them as a specific group (listeners on the rolls, so to speak), the 'developing world audience', and the Third World as a whole.

Transnational radio broadcasting in the Cold War-era generated new spaces - not the 'infinite vicarious universe' of Daniel Lerner's revelry yet, for many people across the globe, a genuine fissure in the familiar, unprecedented in scope, that exposed new worlds and opened new options. Political struggle drove radio's great expansion into the 'Third World', and Radio Moscow was of course a political enterprise, as were the other great 'national radios on an imperializing scale', the VOA and the BBC, and many Third World broadcasters, too. But as the Radio Moscow case shows, the airwaves were as important a 
social space as a political project, and possibly more effective as a social space than anything else.

Year after year, every carefully produced report on Radio Moscow's correspondence contained the same listener critiques: the programming was wooden and generic, "hard on the ears'. Yet, paradoxically, people listened and people wrote. Soviet foreign broadcasting was very much a generic product- a universal by design, not incapacity. But a huge portion of its broadcasting practices -- contests, gift-gifting and correspondence, reading listener letters on air, calling out listeners' names on air-- was oriented toward generating a specific experience of community, a space in the airwaves that reflected an ideal of internationalist intimacy or, in the socialist idiom, 'friendship'. Think again of those huge stacks of letters and surveys waiting for translation in Moscow, and of the Soviet people who would have done that work: for most of them, their primary travel experience in the region of their expertise was in the lines of those letters. (For many of them, it would be their only experience.) And think of a young male listener writing his third letter to Moscow that year, congratulating the Vietnamese on their victory and Brezhnev on his recent speech, requesting more Lenin lessons or African music, suggesting programs about mechanization in agriculture, the Soviet way of life. Who was he? The written record offers a good deal more certainty about Radio Moscow's imagination than his. Like the broadcasting itself, the written record instrumentalises the 'Third World' subject as a vehicle for political aspiration and personal longing. Yet for all its subjectivity, it also suggests that tens thousands of people around the globe did find in Radio Moscow a space for themselves: an internationalist intimacy, a social space of respect and belonging. 
I would like to thank Dina Fainberg and respondents at presentations held at the Universities of Manchester and Oxford, New York University, and the Centre for Contemporary History, Potsdam, and for insightful commentary on previous versions of this essay. Funding for research was provided by the Arts \& Humanities Research Council.

${ }^{1}$ On the genesis of the 'three worlds' concept, see Carl E. Pletsch, 'The Three Worlds, or the Division of Social Scientific Labor, circa 1950-1975', Comparative Studies in Society and History 23, 1981, 4, pp. 565-590. For an important argument about the development of the 'third world' as a utopian, anti-imperialist project by African, Asian, and Latin American leaders themselves, see Vijay Prashad, The Darker Nations: A People's History of the Third World, New York, 2007. The Soviets rejected the term 'third world' on principle, although it does appear occasionally in Soviet sources beginning in the 1970s. The preferred Soviet term was 'developing' (razvivaiushchii) along with variations on the themes of youth ('young countries', 'new countries') and ideology (e.g. 'formerly colonial and capitalist countries'). In this paper, I use the terms 'third world' and 'developing world' as historical artefacts of the era I discuss. For a key early intervention in the field, see David C. Engerman, 'The 
Second World's Third World', Kritika: Explorations in Russian and Eurasian History, 12, 2011, 1, pp. 183-211.

${ }^{2}$ For a contemporary view of the radio boom based on in-depth research in eleven countries, Elihu Katz and E.G. Wedell, Broadcasting in the Third World: Promise and Performance, Cambridge, MA, 1977. See also David Hendy, Radio in the Global Age, New York, 2013; Julian Hale, Radio Power: Propaganda and International Broadcasting,London, 1975; Donald Browne, International Radio Broadcasting: The Limits of the Limitless Medium, Westport, CT, 1982.

${ }^{3}$ Key works include: Daniel Lerner, The Passing of Traditional Society: Modernizing the Middle East, New York, 1958; Wilbur Schramm, Mass Media and National Development: The $\underline{\text { Role of Information in the Developing Countries, Stanford, CA, 1965; Communications and }}$ Political Development, ed. Lucien Pye, Princeton, NJ, 1963. For a useful overview, Katz and Wedell, pp. 3 -37. Political consensus on the need to provide technical assistance to 'Third World' countries to build media capacity grew in the 1960s. Clare Wells, The UN, Unesco, and the Politics of Knowledge, London, 1987, p. 77.

${ }^{4}$ Lerner quoted in Media and Democracy in Africa, eds. Goran Hyden, Michael Leslie, and Foulu Ogundimu, New York, 2002, p. 3.

${ }^{5}$ A few examples: 'Moscow's Bid: The Soviet Line in a Pivotal Region: What Moscow Radio Tells Africa and Asia', New York Times, 2 Sept 1956, p. E1; Tad Szulc, 'Propaganda War: the US and Russian Programs Appraised', New York Times, 8 Sept 1963, p. E3; Kay Barlett, 'Radio War of Words Fills Air Waves Around Globe with Many Languages', Los Angeles Times, 30 Dec 1984, p. 2. Combat imagery also dominates the memoir and scholarly literature on transnational broadcasting, e.g. Michael Nelson, War of the Black Heavens: The Battles of Western Broadcasting in the Cold War, Syracuse, NY, 1997; George R. Urban, Radio Free 
Europe and the Pursuit of Democracy: My War Within the Cold War, New Haven and London, 1997.

${ }^{6}$ Michele Himes, 'Foreword: Transnational Radio in the Global Age', Journal of Radio Studies 11, 2004, 1, pp. iii-vi. Italics mine.

7 James Brennan, 'Radio Cairo and the Decolonization of Africa, 1953-1964', in Christopher Lee (ed.) Making a World After Empire: The Bandung Movement and Its Political Afterlives, Athens, OH, 2010; Peter Partner, Arab Voices: The BBC Arabic Service, 1938-1988, London, 1988.

${ }^{8}$ On evangelical broadcasting, see Tim Stoneman, 'Global Radio Broadcasting and the Dynamics of American Evangelicalism', Journal of American Studies, 51, 2017, 4, pp. 11391170; Richard E. Wood, 'Language Choice in Transnational Broadcasting,' Journal of Communication 29, 1979, 2, pp. 112-123. Radio Cairo and Radio Tanzania lent broadcasting facilities to South African revolutionary groups. L. Mosia, C. Riddle, and J. Zaffiro, 'From revolutionary to regime radio: Three decades of nationalist broadcasting in Southern Africa', Africa Media Review 8, 1994, 1, pp. 1-24.

${ }^{9}$ Cagdas Unghor, 'Reaching the Distant Comrade: Chinese Foreign Propaganda Abroad (1949-1976)', unpublished PhD dissertation, University of Binghamton, 2009. Unghor tracks Radio Peking's expansion from Asia in the PRC's first years to Africa in the late 1950s to the USSR and Eastern Europe in the 1960s. See also the remarkable memoir of Sidney Rittenberg, the first American member of Chinese communist party, who was instrumental at Radio Peking, Sidney Rittenberg, Amanda Bennett, The Man Who Stayed Behind, Durham, NC, 2001.

${ }^{10}$ K.S. Mullick, Tangled Tapes: The Inside Story of Indian Broadcasting, New Delhi, 1974. Hale, Radio Power, p. 84. 
${ }^{11}$ Many of the Soviet republics also broadcast internationally from their capital cities (as of the 1980s, Baku, Vilnius, Dushanbe, Yerevan, Kiev, Minsk, Riga, Tallinn, and Tashkent), and though these operations were supervised by the same party apparatus as central broadcasting in Moscow, the fact that they were tasked with outreach to different regions and initiated some original programming opens interesting questions of comparison and variation. For comparisons among the different broadcasters, see Wood, 'Language Choice in Transnational Broadcasting'.

${ }^{12}$ Simo Mikkonen, 'To control the world's information flows: Soviet Cold War broadcasting', in A. Badenoch, A. Fickers, and C. Henrich-Franke (eds.) Airy Curtains in the European Ether, Baden- Baden, 2013, pp. 241-270; Rossiiskii Gosudarstvennyi Arkhiv Noveishii Istorii (hereafter, RGANI) f. 5, op. 33, d. 177.

${ }^{13}$ Mikkonen, 'To control the world's information flows', p. 247.

${ }^{14}$ Latin America saw a nominal rise in this period (four to 5.5 hours weekly). Gosudarstvennyi Arkhiv Rossiiskoi Federatsii (hereafter, GARF) f. 6903, op. 3, d. 165, II. 4-5; RGANI f. 5, op. 55, d. 18, II. 40-41.

${ }^{15}$ On the early period, Stephen Lovell, Russia in the Microphone Age, Oxford, 2015; T.M. Goriaeva, Radio Rossii: politicheskii kontrol’ sovetskogo radioveshchaniia v 1920-1930-kh godakh: dokumentirovanaia istoriia, Moscow, 1998; A. Sherel', Audiokul'tura XX veka: istoriia, esteticheskie zakonomernosti, osobennosti vliianiia na auditoriiu, Moscow, 2004; P. Gurevich, V. Ryzhikov, Sovetskoe radioveshchanie: stranitsy istorii, Moscow, 1976.

${ }^{16}$ An internal report on broadcasting to India described the cessation of Punjabi broadcasts as 'due to the death of the editorial group's only announcer'. N. Smetanin, 'Radioveschaniia na Indiiu', GARF 6903, op. 3, d. 119a, I. 153; See also L. Belkina, V. Karelina, 'Iz istorii sovetskogo inoveshchaniia (ch.2)', Biulleten' inoveshchaniia, no. 6, 1979, p. 13 in GARF f. 
6903 , op. 46 , d. $53 ;$ I. 13. On the pre-WWII generation of fellow traveller broadcasters, Morten Jentoft, Gud dag! Govorit Moskva! Radio Kominterna, sovetskaia propaganda i norvezhtsy, Moscow, 2013.

${ }^{17}$ Urban, Radio Free Europe and the Pursuit of Democracy, p. x. See also A. Ross Johnson, Radio Free Europe and Radio Liberty: The CIA Years and Beyond, Stanford, CA, 2010; Arch Puddington, Broadcasting Freedom: The Cold War Triumph of Radio Free Europe and Radio Liberty, Lexington, KY, 2003; Simo Mikkonen, 'Exploiting the Exiles: Soviet Émigrés in U.S. Cold War Strategy', Journal of Cold War Studies 14, 2012, 2, pp. 98-127; Friederike KindKovács, 'Voices, Letters, and Literature through the Iron Curtain: Exiles and the (Trans)Mission of Radio in the Cold War', Cold War History: Radio Wars: Broadcasting during the Cold War 13, 2013, 2, pp. 193-219.

18 'Letter to Khrushchev from Radio Moscow Service Urging Creation of Warsaw Pact Station', January 17, 1957, History and Public Policy Program Digital Archive, Archives of the Central Committee of the Communist Party of the Soviet Union. Obtained by Michael Nelson. Translated by Volodymyr Valkov.

<https://digitalarchive.wilsoncenter.org/document/121544>. [accessed 31 July 2020] NB: Translation slightly modified.

${ }^{19}$ Kristin Roth-Ey, Moscow Prime Time: How the Soviet Union Built the Media Empire that Lost the Cultural Cold War, Ithaca and London, 2011; GARF f. 6903, op. 1, d. 734, II. 4-5; GARF f. 6903, op. 1, d. 773, II. 1-17. Several important decrees on improving domestic and foreign broadcasting are included in V. lu. Afiani et al, eds. Apparat TsK KPSS i Kul'tura 19581964: dokumenty, Moscow, 2005.

${ }^{20}$ RGANI f. 5, op. 33 , d. 206, II. 63-75.

${ }^{21}$ GARF f. 6903 , op. 2, d. 294, II. 11-14. 
${ }^{22}$ RGANI f. 5, op. 59, d. 451, II. 36-41. On Radio Peace and Progress, Lada Silina, Vneshnepoliticheskaia propaganda v SSSR v 1945-1985 gg. (po materialam otdela propagandy i agitatsii TsK VKP(b)-KPSS), Moscow, 2011, p. 50.

${ }^{23}$ Representatives of socialist bloc radios did meet regularly to coordinate schedules and frequencies. Silina, Vneshnepoliticheskaia propaganda v SSSR, p. 101; 103. On 1963 proposals for bloc coordination of these technical aspects of broadcasting in Africa, see RGANI f. 5, op. 55, d. 18, II. 128-130; for similar proposals in the late 1970s, RGANI f. 5, op. 69, d. 443. Additionally, Warsaw Pact intelligence services mounted coordinated campaigns against western broadcasting services, RFE/RL in particular. For discussion and archival documents, see Cold War Broadcasting: Impact on the Soviet Union and Eastern Europe, eds. A. Ross Johnson and R. Eugene Parta, Budapest and New York, 2010. As of 1971, Warsaw Pact communist party secretaries in charge of ideological questions met regularly to coordinate international propaganda work, including broadcasting. Their efficacy appears to have been limited. Iu. I. Kandalov, Mezhdunarodnye otnosheniia i ideologicheskoe sotrudnichestvo bratskikh sotsialisticheskikh stran, Moscow, 1981, pp. 162-163. ${ }^{24}$ Himes, 'Foreword'.

${ }^{25}$ M. E. Airapetian, V.V. Sukhodeev, Novyi tip mezhdunarodnykh otnoshenii, Moscow, 1964, p. 208.

${ }^{26}$ The formal division of broadcasting into domestic and foreign services did not happen in the USSR until as late as 1949 - one indication of the unified idea of the audience and of radio's tasks.

${ }^{27}$ GARF f. 6903, op. 3, d. 579, Il. 1-7.

${ }^{28}$ Airapetian, Sukhodeev, Novyi tip mezhdunarodnykh otnoshenii, 73. 
29 'Comrade N.S. Khrushchev's Talk on Oct. 25, 1963 with Participants in the Third World Meeting of Journalists', Current Digest of the Post-Soviet Press, 15, 1963, 43, pp. 14-20. 30 See, for example, comments on radio as a 'second-rank' placement for graduates in Boris Chekhonin, Zhurnalistika i razvedka, Moscow, 2002, p. 25.

${ }^{31}$ Natalia Beglova, 'Spartak-syn Ivana', 2009, <https://proza.ru/2009/10/06/1027> [accessed 31 July 2020].

${ }^{32}$ This was also true for domestic broadcasting culture. When the category of international specialist (mezhdunarodnik) hit Soviet TV screens, it was specialists on western Europe and especially the US who predominated. Latin Americanists were invited on air to talk about Latin America, Africanists about Africa, but the leading Americanist had a regular spot on the evening news and a prime time program. On the intersection of geopolitical and cultural hierarchies, see Rossen Djagalov, From Internationalism to Postcolonialism, Montreal, 2019 and Eleonory Gilburd, To See Paris and Die: The Soviet Lives of Western Culture, Princeton, NJ, 2018.

${ }^{33}$ GARF f. 6903, op. 675, d. 53 also cited in Mikkonen, 'To control the world's information flows', p. 256.

${ }^{34}$ Jentoft, Gud dag! Govorit Moskva!, pp. 210-212. The Indian editorial group is one good example, expanding from a staff of three in the 1940s, all expatriates, to forty-two mostly Soviets in 1957. N. Smetanin, 'Radioveschaniia na Indiiu', GARF f. 6903, op. 3, d. 119a, I. 169.

${ }^{35}$ Oral history interview with S., Moscow, March 2016.

36 'Conditioned by years of colonialism, many African nations are easily swayed by Moscow', warned one journalist. Arnold Beichman, 'Soviet Target: Emergent Africa', Christian Science 
Monitor, 21 March 1961, p. 13'; Peggy Durdin, 'The Grim Lesson of Laos', New York Times, 21 May 1961, p. SM17.

${ }^{37}$ Margaret Peacock, 'Selling Socialism in Suez: Soviet Radio Broadcasting to the MENA during the Suez Crisis' (paper presented at Socialist World, 'Third World', Media Worlds conference, University College London, November 2018); Rosalind Bresnahan, 'Radio and the Democratic Movement in Chile 1973-1990: Independent and Grass Roots Voices during the Pinochet Dictatorship', Journal of Radio Studies, 9, 2002, 1, pp. 161-181; Peter J.

Schmelz, 'Alfred Schnittke's Nagasaki: Soviet Nuclear Culture, Radio Moscow, and the Global Cold War, Journal of the American Musicological Society, 62, 2009, 2, pp. 412-474; Margaret Peacock, Broadcasting Benevolence: Images of the Child in American, Soviet, and NLF Propaganda in Vietnam, 1969-1973', Journal of the History of Childhood and Youth, 3, 2010, 1, pp.15-38.

${ }^{38}$ Silina, Vneshnepoliticheskaia propaganda v SSSR, p. 99.

39 Iosif Amaiakovich ('Joe') Adamov, born in Baku to Armenian parents in 1920, broadcast on RM for more than six decades. For an interview, see $<$ https://www.pbs.org/redfiles/prop/deep/interv/p int joe adamov.htm $>$. [accessed 1 February 2020]. Gary Thatcher, 'Comrade Joe Adamov Tells It All to You', Christian Science Monitor, 9 July 1986. Another example is Luis Cecchini, a political exile from Argentina, who broadcast on the Spanish service from 1932 until the 1980s. Donald Browne, a former Africa-based VOA journalist who visited Radio Moscow in 1970, commented that the North American and British services were both distinguished by their informal delivery style. Browne, International Radio Broadcasting, pp. 224-248.

${ }^{40}$ Vladimir Pozner, Proshchanie s illuziami, Moscow, 2015, p. 236; Arkady Ostrovsky, The Invention of Russia: The Journey from Gorbachev's Freedom to Putin's War, London, 2015, 
p. 183. Paradoxically, many of the journalists who went on to leading roles in the glasnost' era and early 1990s (particularly in television) began at Radio Moscow. The key factor was not broadcast work itself, but the access it afforded to the extra-Soviet world: to foreign publications and broadcasts and to individuals, including guest speakers in the studio and to listener-correspondents. M., Maiofis and I. Kukulin, 'Svoboda kak neosoznannyi pretsedent: zametki o transformatsii mediinogo polia v 1990 godu', Novoe literaturnoe obozrenie, 83, 2007, pp. 599-656.

${ }^{41}$ Renta Lesnik, Ici Moscou, Paris, 1982, p. 90.

42 Jentoft, Gud dag! Govorit Moskva!, p. 200; L. Belkina, V. Karelina, 'Iz istorii sovetskogo inoveshchaniia (ch.2)', Biulleten' inoveshchaniia, no. 6, 1979, p. 28

${ }^{43}$ Problemy inoveshchaniia, no. 1, 1971.

44 'Moscow Mailbag', though unscripted, was pre-recorded and edited. An American visitor to RM in 1958 admired its professionalism. William S. Howell, 'Program Production at Radio Moscow,' Journal of Broadcasting and Electronic Media, 4, 1960, 4, p. 335. Select recordings of 'Moscow Mailbag' are available at the website of the New York public radio affiliate, WNYC: https://www.wnyc.org/series/radio-moscow/listen [accessed 1 February 2020]. An American journalist described Adamov's approach to answering critical listener letters on 'Moscow Mailbag' as 'a sort of "My daddy can beat up your daddy" attitude'. Kay Barlett, 'Radio War of Words Fills Air Waves Around Globe with Many Languages', LoS Angeles Times, 30 Dec 1984, p.2.

${ }^{45}$ Yuri Slezkine, 'The USSR as a Communal Apartment, or How a Socialist State Promoted Ethnic Particularism', Slavic Review, 53, 1994, 2, pp. 414-452.

${ }^{46}$ N.N. Firiubin, Nekotorye voprosy teorii i praktiki diplomaticheskikh peregovorov: uchebnyi material po kursu 'Sov. diplomat. sluzhba', Moscow, 1973, p. 44. 
${ }^{47}$ Frederick Barghoorn, The Soviet Cultural Offensive, Princeton, NJ, 1960, p. 20.

Barghoorn's publications were the subject of careful analysis by the Central Committee apparatus. Silina, Vneshnepoliticheskaia propaganda v SSSR, pp. 61-62.

${ }^{48}$ On 'gigantomania', Paul Josephson, "'Projects of the Century" in Soviet History: Large-

Scale Technologies from Lenin to Gorbachev', Technology and Culture 36, 1995, 3, pp. 519-

559.

${ }^{49}$ RGANI f. 5, op. 33, d. 206, II. 62-75; RGANI f. 5, op. 33, d. 177, II. 62-66.

${ }^{50}$ GARF f. 6903, op. 1, d. 865, II. 61-62.

${ }^{51}$ GARF f. 6903 , op. 1 , d. 865 , I. 12.

${ }^{52}$ For internal criticism of the use of central materials, GARF f. 6903, op. 46, d. 24, II. 40-41;

GARF f. 6903, op. 46, d. 51, I. 11

${ }^{53}$ Philo C. Washburn, 'Voice of America and Radio Moscow Newscasts to the Third World', Journal of Broadcasting and Electronic Media, 32, 1988, 2, pp. 197-218.

${ }^{54}$ Pointedly, Many Voices, One World was the title chosen by the Unesco-convened International Commission for the Study of Communications Problems (the MacBride Commission) for their 1980 report.

${ }^{55}$ Ithiel de Sola Pool, 'Direct-broadcast satellites and cultural integrity', Society, 35, 1998, 2, pp. 140-151. On the NWICO debate, see Wells, The UN, Unesco, and the Politics of Knowledge; Mark Alleyne, International Power and International Communication, London, 1995; Kaarle Nordenstreng, The Mass Media Declaration of Unesco, Norwood, NJ, 1984. ${ }^{56}$ On the history of the BBC Monitoring Service and its collaboration with the US Foreign Broadcasting Information Service, see Alban Webb, London Calling: Britain, the BBC World Service and the Cold War, London, 2014, pp. 81-88. See also the AHRC-funded project 'Listening to the World: BBC Monitoring'. https://www.iwm.org.uk/research/research- 
projects/listening-to-the-world-bbc-monitoring-collection-ahrc-research-network. The bulk of the BBC Monitoring Service reports remains uncatalogued.

${ }^{57}$ On Soviet broadcasting to Vietnam, see Peacock, 'Broadcasting Benevolence'; on Lenin anniversary planning, RGANI f. 5, op. 62, d. 558, II. 24-68; on Afghanistan, Christopher Deal, 'Framing War, Sport and Politics: the Soviet Invasion of Afghanistan and the Moscow Olympics', Unpublished PhD dissertation, Kings College London, 2014.

58 I discuss similar issues around foreign radio listening and para-social interactions in the Cold War, but for the Soviet audience in Kristin Roth-Ey, 'Listening Out, Listening For, Listening In: Cold War Radio Broadcasting and the Late Soviet Audience', The Russian Review, 79, 2020, 4, pp. 556-577.

${ }^{59}$ Alasdair Pinkerton and Klaus Dodds, 'Radio Geopolitics: Broadcasting, Listening and the Struggle for Acoustic spaces', Progress in Human Geography, 33, 2009, 1, p. 20.

${ }^{60}$ Mikkonen, 'To control the world's information flows', p. 246.

${ }^{61}$ Ien Ang, Desperately Seeking the Audience, London, 2006; David Morley, Television, Audiences and Cultural Studies, London, 2003; Jérôme Bourdon, 'Detextualizing: How to Write a History of Audiences', European Journal of Communication, 30, 2015, 1, pp. 7-21.

${ }^{62}$ R. Eugene Parta, Discovering the Hidden Listener. An Assessment of Radio Liberty and Western Broadcasting to the USSR during the Cold War, Stanford, CA, 2007; Alban Webb, 'A Leap of Imagination: BBC Audience Research over the Iron Curtain', Participations, 8, 2011, 1, pp. 154-172; Webb, London Calling, pp. 186-187; Graham Mytton, 'Audiences for International Broadcasts', European Journal of Communication, 3, 1988, pp. 457-481. Gosteleradio staff sent on business trips abroad also gathered information on the reception of broadcasts, but the effort was not systematic. For examples, see GARF f. 6903, op. 32, d. 39; GARF f. 6903, op. 32, d. 40. 
${ }^{63}$ Mytton and Forrester, 'Audiences for International Broadcasts', pp. 471-473. On tiny audiences in India, Howard M. Hensel, 'The Soviet Media and Indian Public Opinion', The Round Table 295, 1985, pp. 240-255.

${ }^{64}$ On Soviet media sociology, see Simon Huxtable, 'In Search of the Soviet Reader: The Kosygin Reforms, Sociology, and Changing Concepts of Soviet Society, 1964-1970, Cahiers du monde russe 54, 2013, 3-4, pp. 623-642; Christine Evans, Between Truth and Time: A History of Soviet Central Television, New Haven, 2016, pp. 47-81; Roth-Ey, Moscow Prime Time, pp. 268-271.

${ }^{65}$ E. Ushakov, 'K nam prishlo pis'mo', Biulleten' inoveshchaniia in GARF f. 6903, op. 46, d. 6, I. 36.

${ }^{66}$ Obzor pisem zarubezhnykh slushatelei Moskovskogo radio poluchennykh v 1973 godu, Moscow, 1974; GARF f. 6903, op. 3, d. 140, I. 3. The figure for 1959 is roughly 100,000 letters, characterized as 'capitalist', 'socialist', and 'Yugoslav'. In the 1960s, the category 'developing world' was introduced, 'Yugoslavia' dropped, and the annual total remained roughly 100,000 .

${ }^{67}$ V. Andrianov, 'Radioveshchanie na strany Latinskoi Ameriki', in GARF f. 6903, op. 3, d. 119a, I. 233.

${ }^{68}$ The frequent scolding of editorial groups for not responding to letters indicates practice fell short of ideals, e.g. GARF f. 6903, op. 10, d. 28. On the number of gifts: Obzor pisem zarubezhnykh slushatelei, p. 3.

${ }^{69}$ The punch card phase of the analysis itself took 4.5 months for the 1974 survey. Anketnyi opros zarubezhnykh slushatelei Moskovskogo radio, vyp. 4, Moscow, 1974, 9.

70 Z. Petrova, 'Chto daet nam anketnoi opros slushatelei',Biulleten' inoveshchaniia, 1975, p. 31 in GARF f. 6903, op. 46, d. 28. 
${ }^{71}$ GARF f. 6903 , op. 46 , d. 54, II. 41-43.

${ }^{72}$ Obzor pisem zarubezhnykh slushatelei Moskovskogo radio poluchennykh v 1973 godu, $p$.

18.

${ }^{73}$ A report on Bulgarian listener letters from a week in July 1962 distinguishes 'complex' letters (66 in total) from 'simple' ones (42) 'in which the radio-listener writes only about himself'. GARF f. 6903, op. 10, d. 28, I. 65.

${ }^{74}$ Obzor pisem zarubezhnykh slushatelei Moskovskogo radio poluchennykh v 1975 godu, Moscow, 1976, p. 39.

75 Ibid., p. 63.

76 Ibid., p. 50.

77 Open-ended questions had a high take up rate in some cases: in the 1980 survey, among Indian listeners, of the 1218 completed, only twenty-eight left the open-ended question blank. GARF f. 6903, op. 46, d. 58, I.5.

${ }^{78}$ GARF f. 6903, op. 46, d. 58, I. 100.

${ }^{79}$ GARF f. 6903, op. 46, d. 58, I. 64.

${ }^{80}$ GARF f. 6903, op. 46, d. 58, I. 10.

${ }^{81}$ GARF f. 6903 , op. 46 , d. 58, I. 77.

${ }^{82}$ GARF f. 6903 , op. 46 , d. 58, I. 36.

${ }^{83}$ GARF f. 6903 , op. 46 , d. 58, 1. 39; II. 21-22.

${ }^{84}$ GARF f. 6903 , op. 46, d. 58, I.114.

${ }^{85}$ GARF f. 6903 , op. 46 , d. 58, I. 67.

${ }^{86}$ GARF f. 6903 , op. 46 , d. 58, I. 71.

${ }^{87}$ Lesnik, Ici Moscou, p. 143; p. 139.

${ }^{88}$ GARF f. 6903 , op. 46 , d. 58, I. 31. 
${ }^{89}$ GARF f. 6903 , op. 46 , d. 58, I. 74.

${ }^{90}$ GARF f. 6903 , op. 46, d. 58, I. 7.

${ }^{91}$ Debra Spitulnik, 'Documenting Radio Culture as Lived Experience: Reception Studies and the Mobile Machine in Zambia', in Richard Fardon and Graham Furniss (eds.) African Broadcast Cultures: Radio in Transition, Oxford, 2000, p. 145.

92 The top three countries for letters logged in 1973 were Japan $(16,750)$, Poland $(14,451)$, and Cuba $(10,829)$. The total for letters from all 'developing countries' was 15,544 . Obzor pisem zarubezhnykh slushatelei Moskovskogo radio poluchennykh v 1973 godu, p. 5; p. 61; p. 74.

${ }^{93}$ Spitulnik, 'Documenting Radio Culture as Lived Experience', p. 157.

${ }^{94}$ On the importance of group listening, GARF f. 6903, op. 46, d. 54, II. 17-18.

95 Japan was also strikingly young: $75 \%$ identified themselves as under the age of twenty in the $1966-1967$ survey, while $96 \%$ self-reported as 'students' in the 1982 survey. GARF $\mathrm{f}$. 6903 , op. 1, d. 998, I. 121 . The exception to the youth rule was the socialist bloc in the later period: by the time of the 1982 survey, the socialist bloc audience was said to be mostly middle-aged, while the developing world audience was dominated by university and school students. f. 6903 , op. 46 , d. 54, II. 7-8.

${ }^{96}$ For some countries, the majority of respondents were self-reported Russian students. The 1982 survey gave a figure of $93 \%$ for Indian listeners under the age of thirty, and of these, 73\% were studying Russian. GARF f. 6903, op. 1, d. 998, II.134-138. VOA research reached the same conclusions about the predominance of students in the RM audience 'Audiences to VOA, BBC, and RM', Washington: USICA Office of Research, Jan. 1981, cited in Browne, International Radio Broadcasting, ch. 8. 
${ }^{97}$ The figures for people reporting to listen via the Clubs of Friends of Moscow Radio were, however, very low. GARF f. 6903, op. 46, d. 54, I.16. 